\title{
The relationship between the chemical composition and lithology of Late Glacial and Holocene biogenic deposits of the Żabieniec mire (Central Poland)
}

\author{
Daniel OKUPNY, *, Ryszard Krzysztof BORÓWKA ${ }^{1}$, Jacek FORYSIAK², Juliusz TWARDY², \\ Marek KLOSS ${ }^{3}$ and Sławomir ŻUREK ${ }^{4}$ \\ 1 University of Szczecin, Institute of Marine and Environmental Sciences, Mickiewicza 16, 70-383 Szczecin, Poland \\ 2 University of Łódź, Department of Geology and Geomorphology, Faculty of Geographical Sciences, Narutowicza 88, \\ 90-139 Łódź, Poland \\ 3 University of Cardinal Stephan Wyszyński, Institute of Biological Science, Wóycickiego 1/3, 01-938 Warszawa, Poland \\ 4 Szareckiego 6/48, 01-493 Warszawa, Poland
}

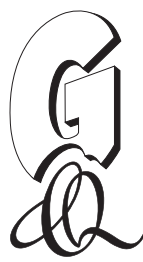

Okupny, D., Borówka, R.K., Forysiak, J., Twardy, J., Kloss, M., Żurek, S., 2021. The relationship between the chemical composition and lithology of Late Glacial and Holocene biogenic deposits of the Żabieniec mire (Central Poland). Geological Quarterly, 65: 11, doi: 10.7306/gq.1579

Associate Editor: Wojciech Granoszewski

Geochemical and plant macrofossil analyses of the Żabieniec mire deposits and the palaeoenvironmental changes they record of the past several thousand years constitute an important source for palaeogeographical reconstruction of the Polish Lowland. We describe the phases of the basin's development from the final part of the Plenivistulian (MIS2), through the Late Glacial and the entire Holocene, encompassing changes determined by both regional and global factors in the surrounding environment, and habitat transformations in the limnogenic mire. The kettle-hole infill of the Żabieniec mire is the only documented example in Central Poland of a succession of biogenic deposits exceeding $10 \mathrm{~m}$ in thickness in such a setting. Deposition initially took place in a lake environment, which led to a shallowing of the lake that persisted until the end of the Mesoholocene.

Key words: kettle hole, limnogenic mire, geochemistry, macrofossils, denudation, Central Poland.

\section{INTRODUCTION}

Peatlands and lakes are important ecosystems, recording their own history as well as the history of past global and local events that variously affected their development (Charman, 2002). Additionally, the role that sites of biogenic accumulation play in the geochemical cycles of major and trace elements is important on a global scale. Depending on the hydrological conditions of lakes and mires, climate change and human activity, biogenic deposits can be characterized by various kinds of lithogeochemistry (Shotyk, 1996; Karasiewicz et al., 2017).

The formation of peat deposits is characterized by a lack of oxygen and water-rich conditions; such environmental conditions contribute to plant decomposition and, afterwards, to various biochemical changes within the deposits. Some contemporary peat bogs and biogenic deposit layers show complex de-

* Corresponding author, e-mail: daniel.okupny@usz.edu.pl Received: May 2, 2020; accepted: December 11, 2020; first published online: March 16, 2021 velopment which included the occurrence of lacustrine and peatbog phases. The waning of lakes results from deposition and should therefore be considered in the context of geological succession (Forysiak, 2012). Kettle hole mires are also formed as a result of terrestrialisation of the water surface and they are defined as small (usually $<1$ ha) but usually deep (locally exceeding $10 \mathrm{~m}$ deep) depression-related wetlands of glacial origin with water supplied from a closed catchment. Kettle holes are a common feature of a young glacial landscape (Kalettka and Rudat, 2006; Karasiewicz et al., 2014; Okupny et al., 2020). In the Saalian glaciated area, individual examples of such forms can generally only be found in northeastern Poland (Żurek, 1990). The Żabieniec mire is the only depression of this type in Central Poland.

Limnogenic peatlands are situated in these local depressions, and thus transport of terrigenous material from the vicinity affects minerogenic supply. Geochemical data are indispensable for the reconstruction of denudation processes around such sites of biogenic accumulation (Borówka, 1992; Pawłowski et al., 2016b). The key assumption of these interpretations is that the main chemical components of biogenic sediments derive from different sources and that they accumulate in deposits in different physico-chemical conditions. In order to re- 
cognise the extent of mechanical denudation, and especially relative changes in this type of process, lithophilic element contents can be used ( $\mathrm{Al}, \mathrm{K}, \mathrm{Mg}, \mathrm{Ti})$, as well as the sums of these elements relative to a normalisation element such as $\mathrm{Ca}$. These components may be supplied passively as quartz and aluminosilicate particles or as ions absorbed by clay minerals (Foster and Dearing, 1987). Through slope erosion, the chemical composition of the material supplied corresponds to the chemistry of local deposits. An important role in the delivery of mineral constituents is also played by wind. Aeolian processes supply mineral constituents that are present in the silt fraction and content of lithophilic elements to peatlands (Rydelek, 2013; Okupny et al., 2019).

This study examines how the major and trace element inputs responded to local and regional environmental influences during the Late Glacial and Holocene at Żabieniec. Plant macrofossils have been used in typology of the sediments and as indicators of the sediments' local habitat conditions. In studying biogenic sediments, macrofossil analysis is vital to distinguish properly between limnic (a layer at the bottom of the lake) and telmatic-terrestrial (settling of autochthonous organic matter) depositional environments. Concentrations of the major elements and trace elements, and the ratios between these, can be used in reconstructions of environmental changes affecting biogenic accumulations and their surroundings. This is a continuation of multi-proxy studies focused on kettle holes located beyond the main stagnation lines of the Vistulian ice sheet (Lamentowicz et al., 2009; Płóciennik et al., 2011; Pawłowski, 2012; Majecka et al., 2018).

\section{STUDY SITE}

The kettle hole mire at Żabieniec (geographical coordinates: $51.85029 \mathrm{~N}, 19.77772 \mathrm{E}$ ) is in Central Poland, $\sim 25 \mathrm{~km}$ east of Łódź (Fig. 1A). It is located in the northern part of the Łódź Hills on a morainic upland $183 \mathrm{~m}$ a.s.l. (Fig. 1B). This region has relatively fewer mires than in other parts of Central Poland (Okupny et al., 2014). The mire is located in a $1.5 \mathrm{~km}$ long, closed oval basin, in the watershed of the rivers Mrożyca (to the west) and Mroga (to the east; Fig. 1C). This basin was formed as a melt-out depression with a very irregular bottom topography when buried ice melted at the end of the Warta Stadial MIS6 (Lamentowicz et al., 2009; Forysiak and Twardy, 2010). It is surrounded by morainic and glaciofluvial hills (Fig. 1C). To the south, the upper section of a large denudational valley leading to the Mrożyca Valley extends to the depression. The Żabieniec kettle is surrounded by a dozen or so depressions, which have been filled of mineral deposits, and protect the deep, central form. The buried segregation ice lenses probably helped preserve it during the Upper Plenivistulian interval, as in the Kleszczów area (Goździk and Konecka-Betley, 1992).

\section{MATERIAL AND METHODS}

\section{FIELDWORK}

The surface geological structure was documented using a hand-held geological drill, and five exposures were also made to show the lithology of the deposits in the mire's direct catchment area. Boreholes were used to determine the geological structure to a depth of several metres. The thickness of biogenic deposits in the area of the mire was investigated using a sampling stick (Forysiak and Twardy, 2010). The sediment core for analysis, Z-2, was collected using a piston corer where the thickest organic deposits were found, in the deepest depression lying in the central part of the mire. The $16.37 \mathrm{~m}$ thick Żabieniec depositional sequence consists of: sand; mineral and organic silt; various types of gyttja and sedge-moss peat; Sphagnum peat; and brown moss peat (Fig. 2). In the laboratory the Z-2 core was divided into five-centimetre slices that were then split for individual analyses.

\section{PALAEOBOTANICAL ANALYSIS}

In the laboratory, gyttja and peat samples were collected from different layers of the core and their palaeobotanical composition was determined. The material for this analysis comprised samples taken at various intervals (between 5 and $110 \mathrm{~cm}$ ), depending on changes in lithology. In total, $48 \mathrm{sam}-$ ples were collected, each with a volume of $\sim 30 \mathrm{~cm}^{3}$. Each sample was boiled in $10 \% \mathrm{NaOH}$, then rinsed under running water on a sieve with a mesh diameter of $0.2 \mathrm{~mm}$. From the fraction that remained on the sieve, 10 microscopic preparations were made from each sample. The residue was identified under a Nikon Eclipse E 200 stereoscopic microscope and the percentage of each of the components distinguished was calculated. In identification of plant macroremains, appropriate keys and atlases were used (e.g., Katz et al., 1977; Tobolski, 2000; Mauquoy and van Geel, 2007). The nomenclature of vascular plants follows Mirek et al. (2002), and that of mosses Ochyra et al. (2003). Changes in the stratigraphy of Z-2 profile representing the kettle hole under study against a depth scale includes six categories (brown mosses; Sphagnum mosses; Ericaceae including Oxycoccus palustris, Ledum palustre and Andromeda polifolia; aquatic plants such as Potamogeton natans and Ceratophyllum demersum; telmatic vegetation; and unidentified plants).

\section{GEOCHEMICAL AND GRAIN-SIZE ANALYSIS}

The investigation concerned 219 samples taken from the Z-2 core (depth 0.02-16.37 m) at $5 \mathrm{~cm}$ intervals. Samples were processed according to the standard procedure (Borówka, 1992). Sediment samples were dried at $105^{\circ} \mathrm{C}$ and homogenised in an agate mortar. The organic matter (OM) content was determined by loss on ignition (LOI) at $550^{\circ} \mathrm{C}$, following the protocol described by Heiri et al. (2001). The Scheibler volumetric method was used to determine the calcium carbonate $\left(\mathrm{CaCO}_{3}\right)$ content of the deposits. The $\mathrm{pH}$ of the deposits was determined by the potentiometric method. The ash produced by combustion was analysed for grain-size-related and geochemical properties.

Grain-size analysis of the mineral part (for 158 samples) was carried out in a Fritsch Analysette 22 laser particle sizer, which processes samples of 300-0.3 $\mu$ m mean grain size. In order to perform geochemical assays, the ash samples were dissolved in Teflon bombs using a microwave mineraliser. Preparation was carried out in two microwave cycles: the first in concentrated nitric acid with $2 \mathrm{ml}$ of $10 \%$ hydrochloric acid and the second in hydrogen peroxide. The solution obtained was analysed for concentrations of $\mathrm{Na}, \mathrm{K}, \mathrm{Ca}, \mathrm{Mg}, \mathrm{Fe}, \mathrm{Mn}, \mathrm{Cu}, \mathrm{Zn}$ and $\mathrm{Pb}$ using atomic absorption spectrometry (AAS). All the analyses were conducted at the Geochemical Laboratory at the University of Szczecin. 


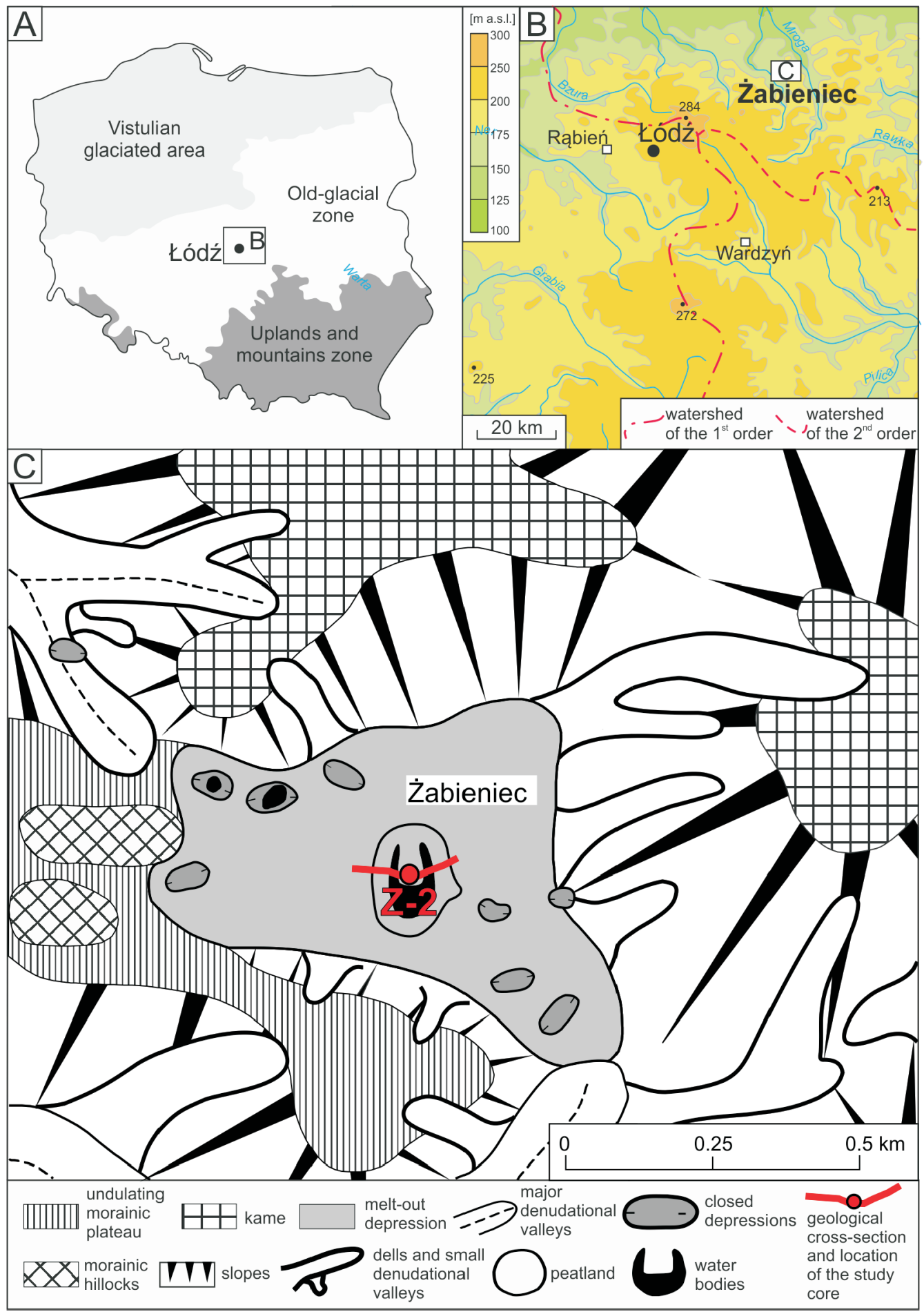

Fig. 1. Location of the Żabieniec site: A - in Poland, B - in the northeastern Łódź Hills, C geomorphological setting of the study area

\section{RADIOCARBON DATING}

Radiocarbon dates were obtained on 12 samples of organic matter or peat layers from the Z-2 core (Table 1). Material for radiocarbon dating was obtained on the basis of macroscopic plant remains (i.e. Sphagnum stems). These samples were dated using accelerator mass spectrometry (AMS) in the Poznań Radiocarbon Laboratory (Poz); all other samples were dated using radiometric methods in the Łódź Radiocarbon Laboratory (Lod). The results of radiocarbon dating and a detailed stratigraphic framework for the Żabieniec mire were published by Lamentowicz et al. (2009) and Pawłowski (2012). Conventional radiocarbon dates were calibrated using OxCal 4.2.2 (Bronk Ramsey, 2009) and the IntCal13 calibration curve (Reimer et al., 2013).

\section{STATISTICAL ANALYSIS}

A geochemical zonation was constructed based on a constrained cluster analysis with PAST version 2.17 c software 
[m a.s.l.]

W

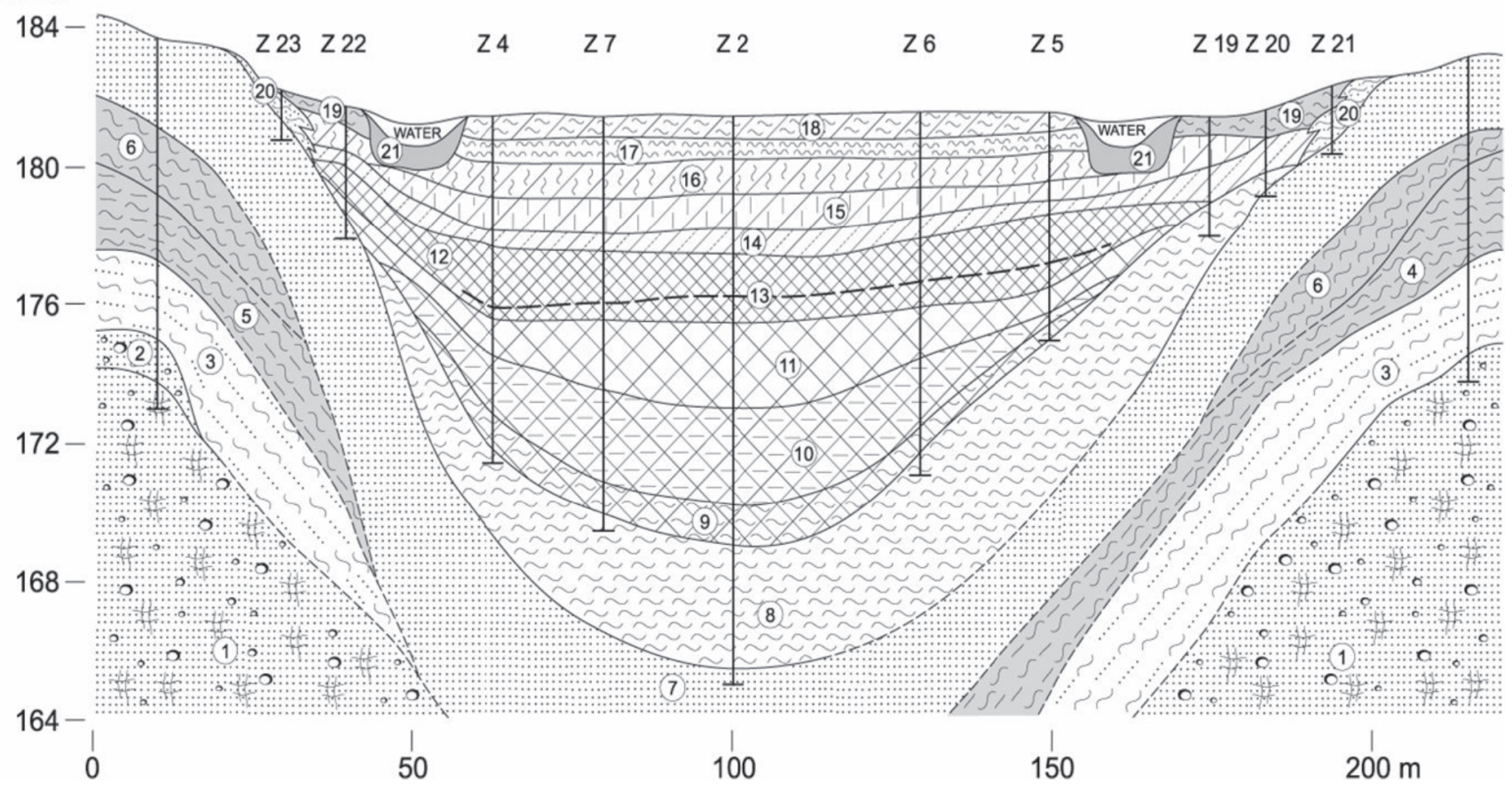

Fig. 2. Geological profile (WE) of the Żabieniec mire (after Forysiak and Twardy 2010, modified)

Warta Glaciation (=Saalian): 1 - glacial till, 2 - fluvioglacial sand and gravel, 3 - mineral silt; Eemian Interglacial: 4 - organic silt; Vistulian (=Weichselian): 5 - mineral-organic silt with fine sand, 6 - organic-mineral silt, 7 - sand, 8 - mineral and organic silt, 9 - gyttja with silt, 10 detritus-clay gyttja; Holocene: 11 - fine detritus gyttja, 12 - coarse detritus gyttja, 13 - brown-moss peat, 14 - sedge-moss peat, 15 - Sphagnum peat, 16 - sedge-moss peat, 17 - Sphagnum cuspidatum peat, 18 - sedge-moss peat and brown moss peat, 19 - organic-mineral silt with detritus, 20 - silt, 21 - deposits disturbed by exploitation

(Hammer et al., 2001). The cluster analysis applied for the purpose was based on constrained incremental sum-of-squares clustering. This frequently used method is thought to be one of the best agglomeration techniques (Mangiamelli et al., 1996). The percentage contributions of individual fractions and textural parameters such as mean diameter (Mz), sorting (SD), skewness (Sk) and kurtosis (KG) were calculated according to Folk and Ward (1957) and using GRADISTAT software (Blott and Pye, 2001).
Principal Component Analysis (PCA) is one of the basic ordination techniques applied to data in palaeolimnology (Legendre and Birks, 2012). This statistical technique is used to determine the variability of factors controlling the chemical composition of lake and peat deposits. This analysis was performed on a correlation matrix of major and trace elements, organic matter and non-carbonate mineral matter. To assign the same weight to all measurements, each variable in the original data set was standardised by subtracting its mean and then dividing

Table 1

Results of radiocarbon dating of deposits from the Z-2 core (after Lamentowicz et al., 2009; Forysiak, 2012, modified)

\begin{tabular}{|c|c|c|c|c|c|}
\hline & \multirow{2}{*}{$\begin{array}{c}\text { Depth } \\
\text { sample } \\
{\left[\begin{array}{c}\text { [cm] } \\
\end{array}\right.}\end{array}$} & Lab code & \multirow{2}{*}{$\begin{array}{c}\text { Radiocarbon } \\
\text { age (BP) }\end{array}$} & \multicolumn{2}{|c|}{$\begin{array}{c}\text { Calibrated age } \\
\text { (cal BP) } 95 \%\end{array}$} \\
\cline { 5 - 6 } & & & intervals & median \\
\hline 1 & 45 & Poz-19019 & $645 \pm 50$ & $674-545$ & 606 \\
\hline 2 & 60 & Poz-17117 & $1085 \pm 30$ & $1056-935$ & 992 \\
\hline 3 & 120 & Poz-17116 & $1475 \pm 35$ & $1415-1298$ & 1360 \\
\hline 4 & 305 & Lod-1391 & $3010 \pm 50$ & $3359-3063$ & 3212 \\
\hline 5 & 375 & Lod-1390 & $3690 \pm 50$ & $4220-3886$ & 4030 \\
\hline 6 & 436 & Poz-23658 & $4580 \pm 35$ & $5448-5057$ & 5298 \\
\hline 7 & 531 & Poz-23638 & $6270 \pm 40$ & $7274-7025$ & 7208 \\
\hline 8 & 826 & Poz-23639 & $9130 \pm 50$ & $10479-10204$ & 10289 \\
\hline 9 & 1036 & Poz-23640 & $11860 \pm 60$ & $13858-13479$ & 13713 \\
\hline 10 & 1290 & Poz-23659 & $14120 \pm 70$ & $17521-16900$ & 17168 \\
\hline 11 & 1355 & Poz-29620 & $26240 \pm 90$ & $30698-31169$ & 30968 \\
\hline 12 & 1535 & Poz-29713 & $18330 \pm 90$ & $22236-21510$ & 21873 \\
\hline
\end{tabular}


by its standard deviation: $a_{i j}=\left(x_{i j}-x_{j}\right) / \sigma_{j}$, where $a_{i j}$ is the value after standardisation, $x_{i j}$ is the value before standardization, $x_{j}$ is the mean value of geochemical properties and $\sigma_{j}$ is the standard deviation.

The Pearson correlation matrix was calculated separately for 10 chronozones. The profile was divided on the basis of chronology, i.e. independently of the geochemical features analysed. The variability in conditions of sedimentation was estimated on the basis of the correlations of results of different measurements as was done by Walanus (2000). In the case of the Z-2 core, the $|r|$ marker was calculated for 10 variables (geochemical properties) as a moving mean.

In order to determine the intensity of migration of major and trace elements of fill deposits, use was made of the procedure proposed by Borówka (1992): $K_{x}=A C_{x} / n_{x}$ (where: $A C_{x}$ - the content of element $x$ in the ash from deposits filling a biogenic accumulation reservoir, $n_{x}$ - the average content of element $x$ in the bedrock and, as a result we obtained a dimensionless coefficient of the concentration of element $-K_{x}$ ). The geochemical background was calculated as the average of the results of determinations of individual elements for deposits of the Żabieniec mire substratum (sandy deposits underlying a series of biogenic deposits in the Z-2 profile) and clayey sands and tills, which constitute the parent rock for soils of the northeastern Łódź Hills (Konecka-Betley and Czępińska-Kamińska, 1979).

\section{RESULTS}

\section{GEOLOGICAL AND GEOMORPHOLOGICAL STUDIES}

In its natural state, the entire surface of the mire was covered by peat. The immediate surrounding of the mire is composed of mineral-organic silts deposited in the Holocene and Late Glacial. The mire is the lowest part of a meltout basin. Farther from the mire, the surface is built of Late Glacial deluvial sands and silts (Forysiak and Twardy, 2010). Nowadays, between the surface of the mire and meltout basin surrounding it, there is a height difference of $\sim 2-3 \mathrm{~m}$. Within it catchment there are several small buried meltout kettle-holes, most of them filled with mineral and mineral-organic deposits. Larger height differences (of 10 metres or a little more) are visible on the slopes of the basin. The lower parts of the slopes consist mainly of sands and deluvial silts, while the middle and upper sections are made of glacial and glaciofluvial sands and gravels and glacial till, deposited during the Saalian Glaciation (Warta Stadial). In addition, palynological analysis of the core taken from the edge of the Żabieniec kettle hole indicated the presence of Eemian material at the depth of $\sim 10 \mathrm{~m}$ (Forysiak and Twardy, 2010).

\section{RESULTS OF PLANT MACROFOSSIL ANALYSIS}

15 local plant macrofossil assemblage zones (L MAZ: Z2-ma-I to Z2-ma-VII) were distinguished in the sediment core from the central part of the Żabieniec mire. The zones correspond to the seven basic stages of wetland development (Fig. 3). The graph shows the percentage share of plant macrofossils in the biogenic deposits of the zones recognized, the percentage values of individual components in the respective zones totalling $100 \%$.

Z2-ma-I (3.80-8.30 m, lake reservoir): detrital gyttja with layers of moss peat accumulated in the depression. Z2-ma-la $(6.05-8.30 \mathrm{~m})$ : corresponds to fine detrital gyttja with an intercalation of coarse detritus gyttja, in which the share of Drepanocladus aduncus reaches $\sim 50 \%$. There are numerous fragments of aquatic plants throughout the layer, such as Potamogeton natans and Ceratophyllum demersum. At the depth of $3.80-6.05 \mathrm{~m}$ of the core there is a peculiar interlayering of coarse detritus gyttja (Z2-ma-lc, e, g) and moss peat (Z2-ma-lb, d, f). The presence of mossy plant communities indicates periods when the lake became shallow. In the Z2-ma-lb to $d$ levels, at the depths 5.90-6.05 m and 5.20-5.40 m, there was a floating mat built of Drepanocladus sendtneri. In the Z2-ma-If level at the depth of 4.05-4.10 m, Pseudocalliergon trifarium dominates. At these, brown mosses were occasionally accompanied by sedges and peat mosses.

Z2-ma-II (3.20-3.80 m, fen): at the end of the Atlantic period, after the lake had become shallow, continuous accumulation of peat took place in the Żabieniec mire basin.

Z2-ma-Ila, Caricetum lasiocarpae bryopsidaetosum, 3.60-3.80 m. Drepanocladus sendtneri and Pseudocalliergon triforium predominate in a wet layer of moss peat.

Z2-ma-Ilb, Caricetum lasiocarpae typicum, 3.20-3.60 m. The share of brown mosses decreased in the plant communities. Sedges prospered, namely: Carex lasiocarpa, C. nigra, C. rostrata and C. elata.

Z2-ma-III (1.20-3.20 m, transition bog): in the middle of the Subboreal the inflow of groundwater from the surrounding catchment was reduced. In the surface layer, wet conditions developed under the influence of capillary rise, as precipitation increased.

Z2-ma-Illa, Caricetum lasiocarpae sphagnetosum, 2.15-3.20 m. Sedge-moss communities were characterized by a large share of Carex lasiocarpa, C. nigra, Scheuchzeria palustris, and Eriophorum angustifolium. There was a small admixture of peat mosses.

Z2-ma-Illb, Scheuchzerio-Caricetum limosae, 1.20-2.15 m. Scheuchzeria palustris and Carex lasiocarpa appeared alongside C. limosa. There was a large share of Sphagnum magellanicum, S. subsecundum and, less frequently, S. fallax peat mosses. Among the plant remains, Oxyccocus palustris and Ledum palustre dwarf shrubs were also identified.

Z2-ma-IV (Sphagnetum magellanici, 0.62-1.20 m, raised bog): in the first half of the Subatlantic the beginning of raised bog peat accumulation was recorded. The bog became subject to an ombrotrophic water regime. This phase was characterized by the dominance of peat moss - mainly Sphagnum magellanicum. Dwarf shrubs were present - Oxycoccus palustris, Ledum palustre, Andromeda polifolia. Remains of Eriophorum vaginatum and Scheuchzeria palustris were also identified.

Z2-ma-V (Sphagnum-Carex rostrata, 0.38-0.62 m, transition bog): the plant community was dominated by the peat mosses Sphagnum magellanicum and $S$. fallax. The ombrotrophic dwarf shrubs Ericaceae and Eriophorum vaginatum were present. The share of sedges increased, including Carex rostrata and C. elata.

Z2-ma-VI (Carex nigra-Carex elata, 0.15-0.38 m, fen): the plant community was dominated by the sedges Carex nigra, C. elata, C. rostrata and C. lasiocarpa. The peat mosses and brown mosses disappeared. The development of a Carex nigra-Carex elata community attests to a marked increase in the habitat's richness in minerals.

Z2-ma-VII (Sphagnum fallax-Carex nigra, 0.00-0.15 m, transition bog): peat mosses reappeared among the plants identified. These were mainly Sphagnum palustre and $S$. fallax. The plant community composition was also characterized by the presence of the sedges Carex nigra, $C$. canescens and remains of the Poaceae grasses. The brown mosses included Straminergon stramineum and Brahythecium rivulare. 


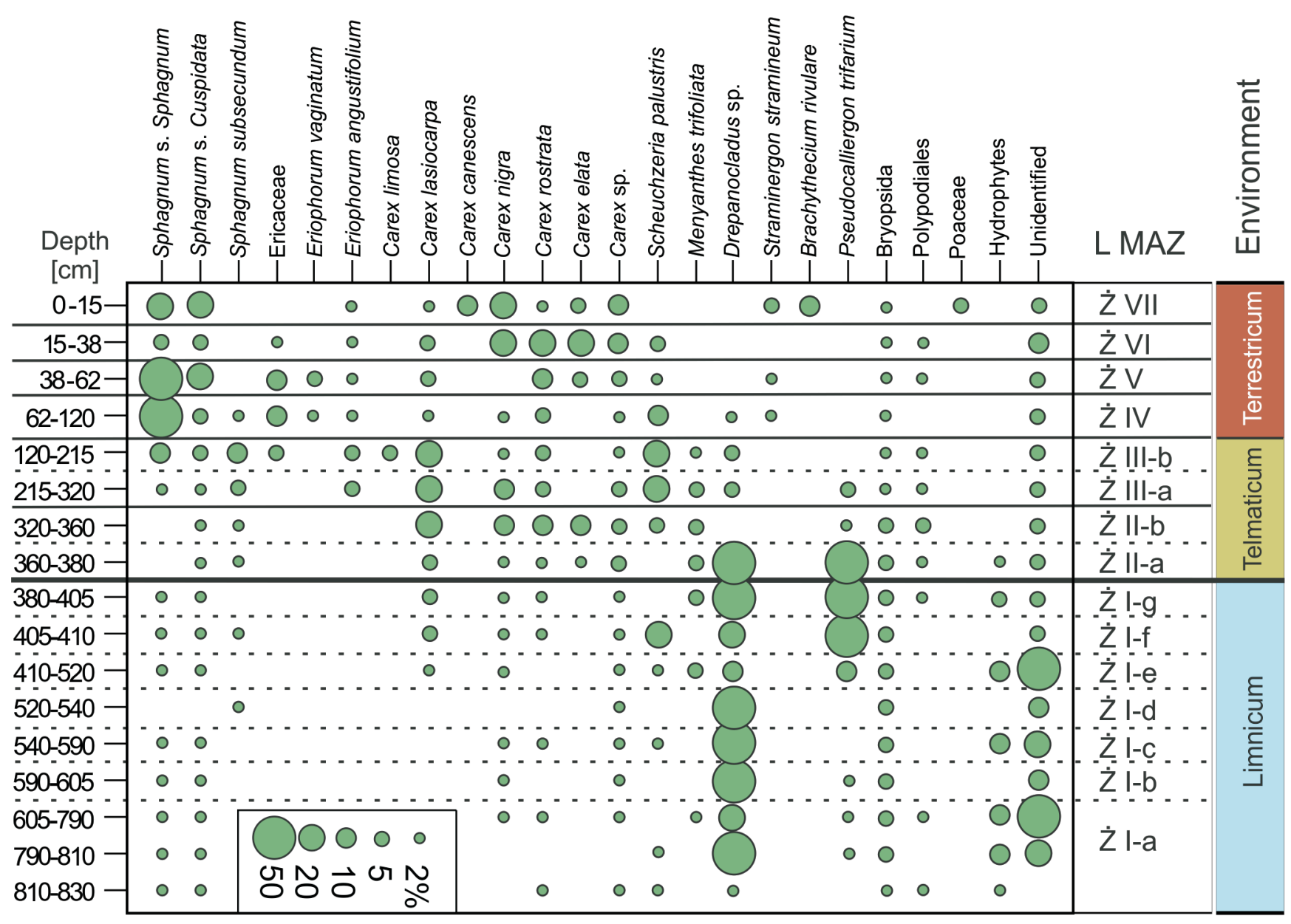

analysis M. Kloss

Fig. 3. Botanical composition of biogenic deposits from Z-2 core

\section{GEOCHEMICAL AND TEXTURAL STRATIFICATION} OF THE Z-2 CORE

Based on the varying contents of two main components of deposits (OM and MM) and macro- and microelement concentrations, seven main geochemical zones are distinguished, coded GZ I-VII (Figs. 4 and 5).

GZ I (16.12-16.37 m) - represents sands varying in grain size (Fig. 4). The median (Mz) for these deposits ranged from 2.25 to 3.19 phi, and the mean was 2.67 phi (Fig. 5). They have low OM content (up to $\sim 0.9 \%$ ), while $\mathrm{CaCO}_{3}$ is completely lacking, and all elements are in low concentrations (Fig. 4).

GZ II (14.62-16.1 m) - is composed of very fine-grained sands with mineral matter averaging $97.5 \%$. The sediments analysed are moderately sorted (SD ranged from 1.13 to $1.4 \mathrm{phi}$ ). They are characterized by high contents of $\mathrm{Mn}$ (average is $5.3 \mathrm{mg} / \mathrm{g}$ ), Fe (average is $9.9 \mathrm{mg} / \mathrm{g}$ ), $\mathrm{K}$ (average is $2.18 \mathrm{mg} / \mathrm{g}$ ) and $\mathrm{Pb}$ (average is $11.1 \mu \mathrm{g} / \mathrm{g}$ ). The Fe/Mn ratio is minimal throughout the whole profile (average is 1.81). The sediment $\mathrm{pH}$ is neutral $(6.8-7.2)$.

GZ III (11.05-14.62 m) - represents moderately sorted sandy silt (Mz ranged from 3.14 to 4.99 phi and SD ranged from 1.05 to 1.4 phi). It has low OM content (up to $\sim \%$ ) and a gradual increase in $\mathrm{CaCO}_{3}$ content (from 10 to 16\%). This zone is distinguished by the highest concentrations of $\mathrm{Mg}$ (up to $5.7 \mathrm{mg} / \mathrm{g}$ ) and $\mathrm{K}$ (up to $3.67 \mathrm{mg} / \mathrm{g}$ ). This results in very high $\mathrm{Na}+\mathrm{K}+\mathrm{Mg} / \mathrm{Ca}$ and very low $\mathrm{Na} / \mathrm{K}$ ratios. The sediment $\mathrm{pH}$ is still neutral, often exceeding 7.0.
GZ IV (8.32-11.05 m) - represents detrital-clay gyttja with the OM content gradually increasing upwards in the profile to its maximum values (of $63.8 \%$ ) at $8.47 \mathrm{~m}$ depth. These are mainly silt deposits (mean $69.8 \%$ ), with $\sim 25.1 \%$ of sand. Very fine silt and clay account for only $5 \%$. The concentrations of $\mathrm{Ca}, \mathrm{Mg}, \mathrm{Mn}$ and content of $\mathrm{CaCO}_{3}$ decrease. The sediments of this zone have high $\mathrm{K}$ and $\mathrm{Na}$ contents, which are also the maximum concentrations for the whole profile at $5 \mathrm{mg} / \mathrm{g}$ and $0.37 \mathrm{mg} / \mathrm{g}$, respectively. The $\mathrm{Fe} / \mathrm{Ca}$ ratio is highest $(>3)$ of all the zones in the core. The $\mathrm{pH}$ decreases abruptly in this zone (from 7.8 to 4.5 ). GZ V (4.05-8.32 m) - is distinguished by a rapid decrease in lithophilic element contents ( $\mathrm{Na}, \mathrm{K}$ and $\mathrm{Mg}$ ). Only $\mathrm{Zn}$ increased in this zone (to $328.6 \mu \mathrm{g} / \mathrm{g}$ ), while the concentrations of $\mathrm{Cu}$ and Fe fluctuate around their average values calculated for the whole core. The OM content increases in the brown moss peat (to $96.4 \%$ ). This zone has low $\mathrm{Fe} / \mathrm{Mn}, \mathrm{Fe} / \mathrm{Ca}$ and $\mathrm{Na}+\mathrm{K}+\mathrm{Mg} / \mathrm{Ca}$ ratios. The three periods of increased $|r|$ values corresponds with the periods of increased $\mathrm{Na} / \mathrm{K}$ and $\mathrm{Cu} / \mathrm{Zn}$ ratios. The $\mathrm{pH}$ of the deposits is also low, not exceeding 5.8.

GZ VI $(0.45-4.05 \mathrm{~m})$ - represents the sedentation of autochthonous rock-forming matter (increase in OM content to 97.9\%) and associated changes in $\mathrm{Na} / \mathrm{K}, \mathrm{Fe} / \mathrm{Mn}$ and $\mathrm{Cu} / \mathrm{Zn}$ ratios. The concentrations of $\mathrm{Ca}, \mathrm{K}, \mathrm{Mg}, \mathrm{Zn}$ and $\mathrm{Fe}$ are also low, while the contents of other elements fluctuate around their average values calculated for the whole profile. The two periods of increased $|r|$ values correspond with decreases in Fe/Mn and 

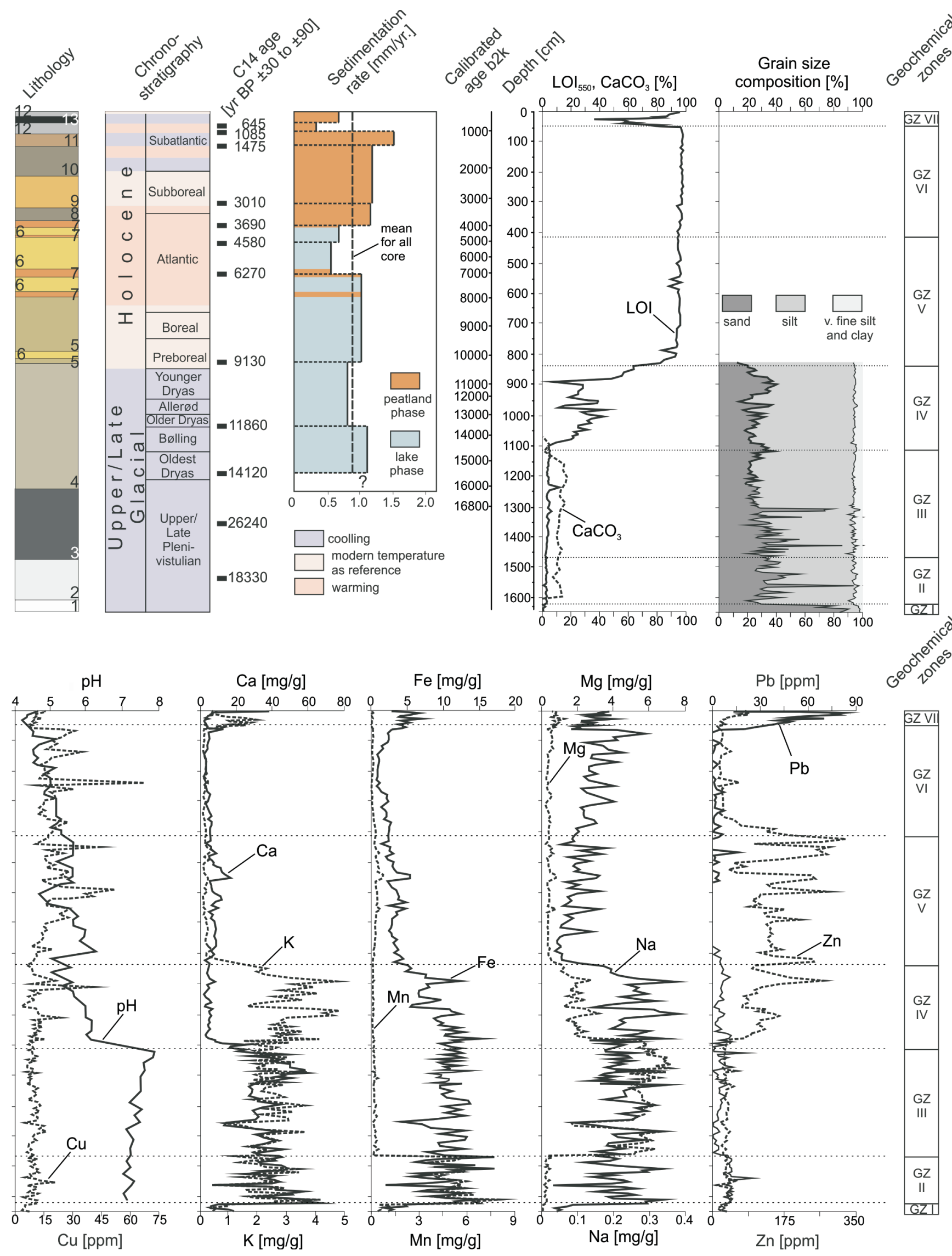

Fig. 4. Geochemical characteristics and percentage share of selected granulometric fractions of the Żabieniec deposits (Z-2 core) against the climate history (after Tolksdorf and Kaiser, 2012)

Lithology: 1 - sand with scattered organic material, 2 - fine-grained lacustrine sand with silt, 3 - lacustrine silt with sand, 4 - detrital-clay gyttja, 5 - fine detrital gyttja, 6 - coarse detrital gyttja, 7 - brown moss peat, 8 - sedge-moss peat, 9 - bog moss peat, 10 - moss-sedge peat, 11 - Sphagnum peat, 12 - sedge peat, 13 - moss-sedge peat 


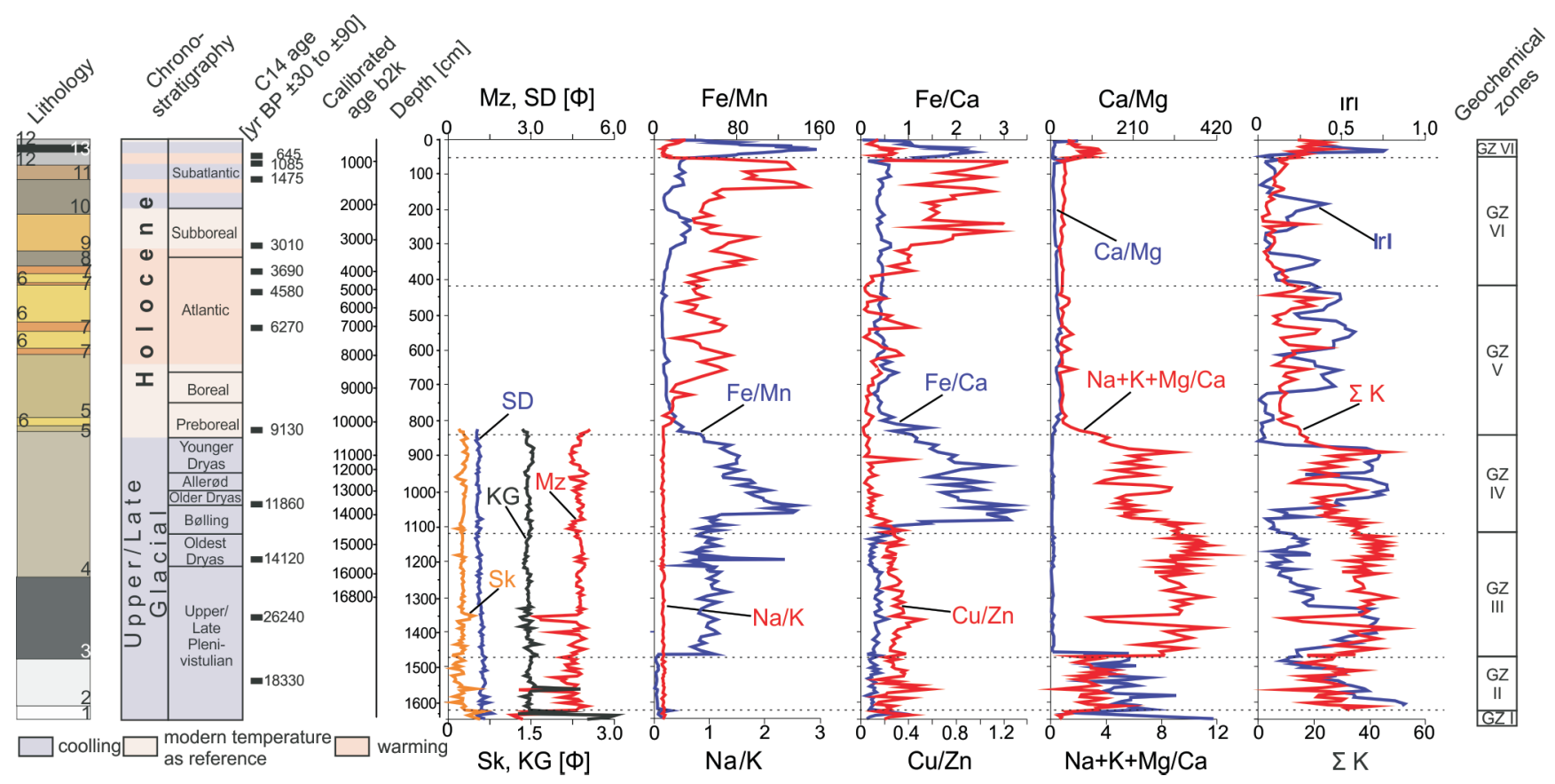

Fig. 5. Vertical differences in selected lithogeochemical parameters and textural parameters within the Żabieniec (Z-2 core) deposits

Explanations as in Figure 4

$\mathrm{Cu} / \mathrm{Zn}$ ratios. The peat-forming community was characterized by strong acidification ( $\mathrm{pH}$ range 4.3-5.2).

GZ VII $(0.00-0.45 \mathrm{~m})$ - is composed of sedge peat and sedge-moss peat with very varying OM content (36-95.4\%), which reaches three maxima exceeding $80 \%$. The only low concentrations are of $\mathrm{Cu}$ and $\mathrm{Mn}$, while the concentrations of other elements fluctuate well above their average values calculated for the whole core. The $\mathrm{Fe} / \mathrm{Mn}, \mathrm{Fe} / \mathrm{Ca}, \mathrm{Na}+\mathrm{K}+\mathrm{Mg} / \mathrm{Ca}$ and $|r|$ ratios increase in this zone. The acidity of the sediment continues to stay at 4.3-4.7.

The first two factors are significant (PC1 and PC2), which explains a total of $64 \%$ of the variance (Fig. 6A). The first component (PC1), which explains $50 \%$ of the total variation, is explained mainly by the content of lithophilic elements ( $\mathrm{Na}, \mathrm{K}, \mathrm{Mg}$ ) and to a lesser extent by the organic matter. The second component (PC2) is less important (it explains $14 \%$ of the geochemical variability of the deposits). This eigenvector is explained mainly by $\mathrm{Cu}, \mathrm{Zn}, \mathrm{Mg}$ and $\mathrm{Na}$ contents, and to a lesser extent by concentrations of $\mathrm{Ca}, \mathrm{Pb}$ and $\mathrm{Mn}$ (Fig. 6B). The factor value curves in the $Z-2$ profile indicate a close relationship between changes in lithogeochemical component contents and lithological changes (Fig. 6C).

\section{INTERPRETATION AND DISCUSSION}

\section{DEVELOPMENT HISTORY OF THE ŻABIENIEC MIRE}

7 phases of mire development and palaeonvironmental change are distinguished in the Żabieniec site and the surrounding area, and the correlation between these and the lithogeochemical succession is compiled in Figure 7, while the lithology, chronostratigraphy and macrofossil biostratigraphic and geochemical zones are summarised in Figure 8.
PHASE 1: LAKE-BOTTOM FORMATION

$(16.40-16.10 \mathrm{~m} ; \sim 22,000-20,000$ cal yr BP $)$

This phase includes mineral deposits forming the substrate for the overlying basin infill. This unit is made up of Plenivistulian and Late Glacial sands and silts resulting from denudation in cold climate conditions. Similar deposits also make up the bottom part of the infills of buried depressions in the vicinity of the mire (Forysiak and Twardy, 2010; Forysiak et al., 2017; Majecka et al., 2018). They are characterized by a low content of lithophilic elements, resulting in very low $\mathrm{Na} / \mathrm{K}$ and $\mathrm{Na}+$ $\mathrm{K}+\mathrm{Mg} / \mathrm{Ca}$ ratios. A further phase of biogenic accumulation - after the final shaping of the lake basin - was determined by climatic and hydrogeological factors and the morphology of the lake basin, as well as the processes taking place in its direct catchment area. Among these processes were the formation of numerous syngenetic ice wedges and other subterranean ice types and, under increasingly arid conditions, a reduction in vegetation cover as well as increasing wind activity. These processes were the initial stages in development of numerous reservoirs in Central Poland (Goździk and Konecka-Betley, 1992; Bezkowska, 1997; Klatkowa, 1997).

$$
\begin{aligned}
& \text { PHASE 2: UPPER/LATE GLACIAL LAKE SEDIMENTATION ENVIRONMENT } \\
& (16.10-9.00 \mathrm{~m} ; 22,000-11,500 \text { cal yr BP })
\end{aligned}
$$

The lake sediments recorded during this phase have highly variable concentrations of almost all elements and grain sizes, with many sandy and silty intercalations. The bulk geochemical composition of the profile analysed can be divided into four subphases of the lake's development at Żabieniec.

In the bottom part (below $14.62 \mathrm{~m}$ ) the sediments have alkaline geochemistry, probably related to the decalcification of the catchment area (sediment pH often exceeds 7.0 with a calcium carbonate content of 6 to 13\%). Relations between OM, MM 


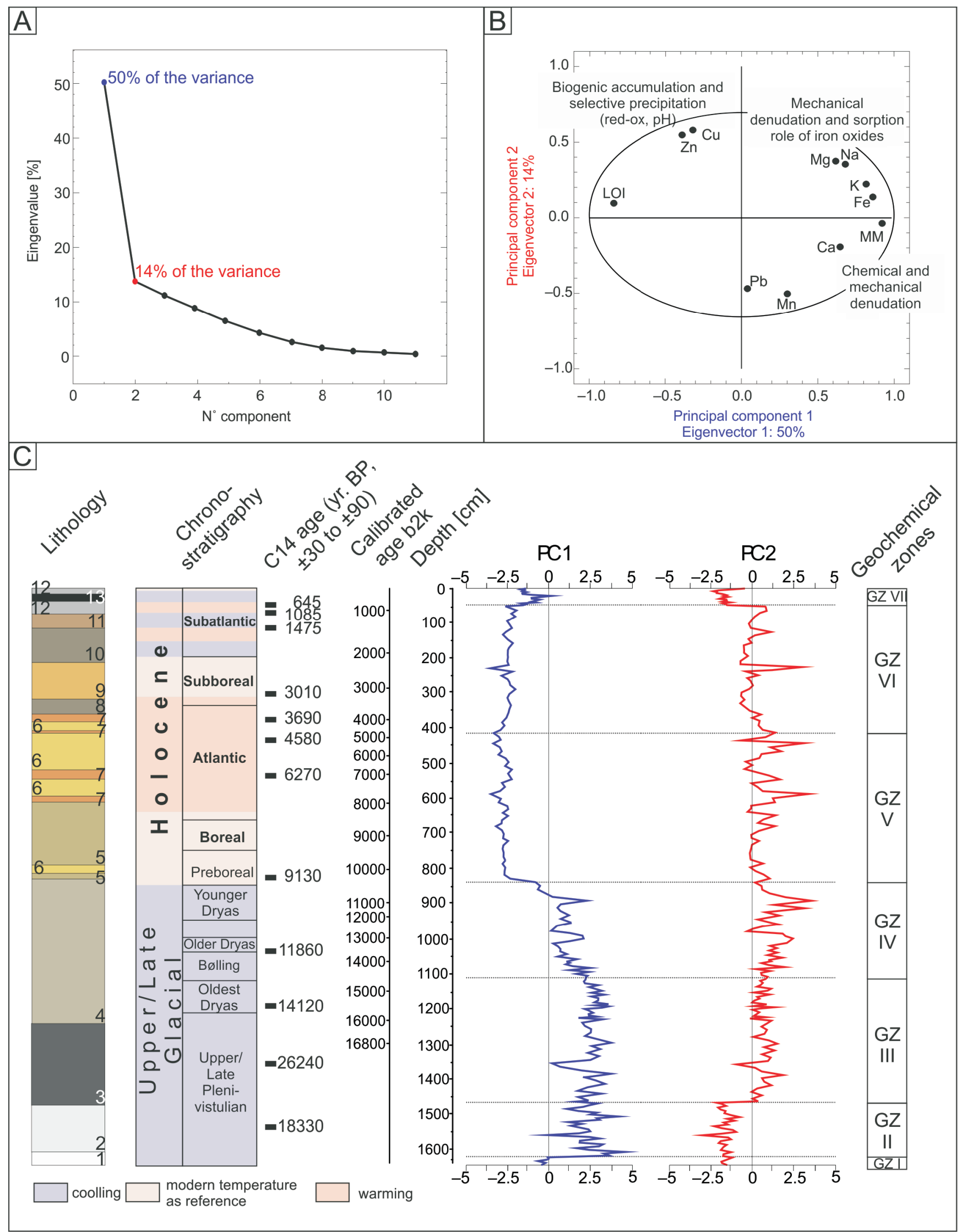

Fig. 6. Results of principal component analysis (PCA) for the Z-2 core

A - eigenvalues of correlation matrix for a set of results of chemical analysis for deposits of the Z-2 core; B - correlation of geochemical variables with the two first principal components; $\mathbf{C}-$ plots of factor scores (PC1 and PC2); explanations as in Figure 4 


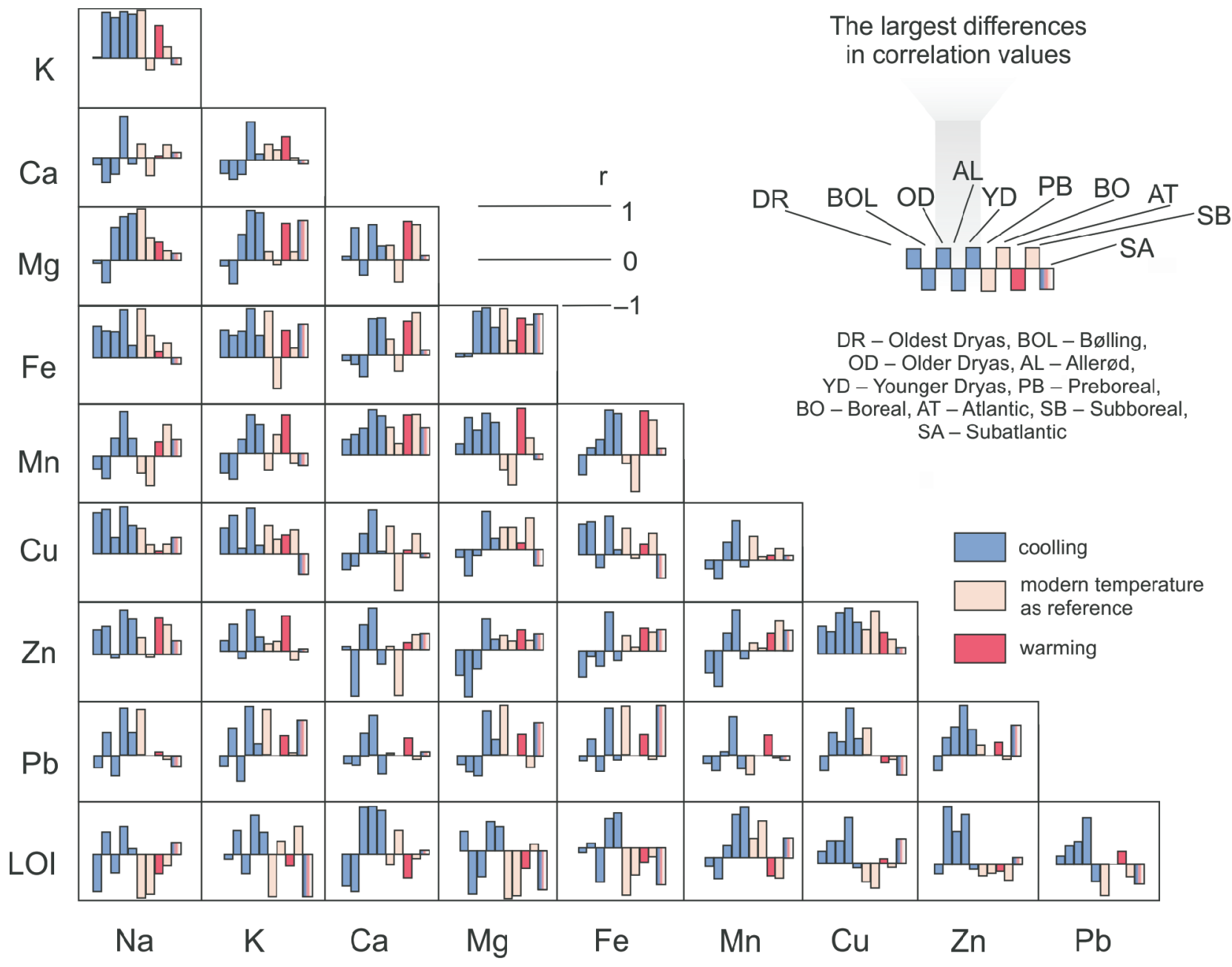

Fig. 7. Correlations between 10 analysed quantities

Correlation coefficients $(r)$ are calculated for each pair of geochemical properties in 10 geological intervals independently for the Z-2 core

and $\mathrm{CaCO}_{3}$ are typical of clay and clay-calcareous gyttjas. A high calcium carbonate content in the initial phase of the lake basin may have been cryochemically introduced in part. According to Bukowska-Jania (2003), cryochemical calcium carbonate crystallising under periglacial conditions was maximally susceptible to redissolution and migration, and was the first to reach the meltout depressions. However, accumulation of calcium carbonate in tundra water bodies with the participation of aquatic vegetation cannot be ruled out. The oxidising conditions prevailing in the lake basin enabled the precipitation of manganese compounds.

At a depth of 14.62 to $12.00 \mathrm{~m}$ lacustrine silt with sand mainly occurs, with a low concentration of copper and zinc. However, the most dramatic decrease in precipitation in the lake basin was of manganese, the concentration of which decreased almost thirtyfold in the section studied. Probably, as climate ameliorated prior to the Kamion phase, lake level rose, leading to a reduction in oxygen levels in the bottom zone, thus strongly limiting the precipitation of manganese hydroxide (Łącka et al., 1998). Also, with a higher water level, surface runoff from the lake could have started, resulting in at least a partial outflow of dissolved manganese compounds.

The chemical composition of the next subphase (depth $9.00-12.0 \mathrm{~m}$ ) records environmental changes in the interval immediately preceding the Holocene. The Late Glacial began with a change in sedimentary character, as already recorded in detrital-clay gyttja with low organic matter content (3-5\%), slightly higher $\mathrm{pH}$ (average $\mathrm{pH} 7.5$ ) and a high proportion of calcium carbonate (14-16\%). The silt grain size (homogeneous silt with some very fine sand) indicates stable conditions for the supply of fine mineral material from the catchment, and the abundance of this sediment suggests that the area had poor vegetation coverage. This stage of the reservoir's development is also recorded in an increase in iron concentration, especially in relation to the manganese and calcium contents. The first period in which reducing conditions dominated, as expressed by a sharp increase in the Fe/Mn ratio, was documented for the Oldest Dryas. However, the highest value of this indicator (of >150) was found for lake sediments deposited as the Bølling gave way to the Older Dryas. In the Oldest Dryas the catchment erosion rate is also at its maximum $(\mathrm{Na}+\mathrm{K}+\mathrm{M} / \mathrm{Ca}>11)$ and the sedimentation dynamics index $|r|$ doubles. The lake basin was then being filled at a rate of $\sim 1.2 \mathrm{~mm} / \mathrm{year}$, which is higher than the average for the entire Z-2 profile $(0.9 \mathrm{~mm} /$ year $)$. The Older Dryas sediments also saw a marked increase in $\mathrm{Zn}$ concentration, which is probably related to an influx of birch leaves into the lake, these having a particularly high bioaccumulation capability for this metal (Fortescue, 1980). This, in turn, may explain the increase in trophic index ( $\mathrm{Fe} / \mathrm{Ca}$ value often $>3$ ) and the moderately high organic matter content (31-42\%). In the Late-Glacial 


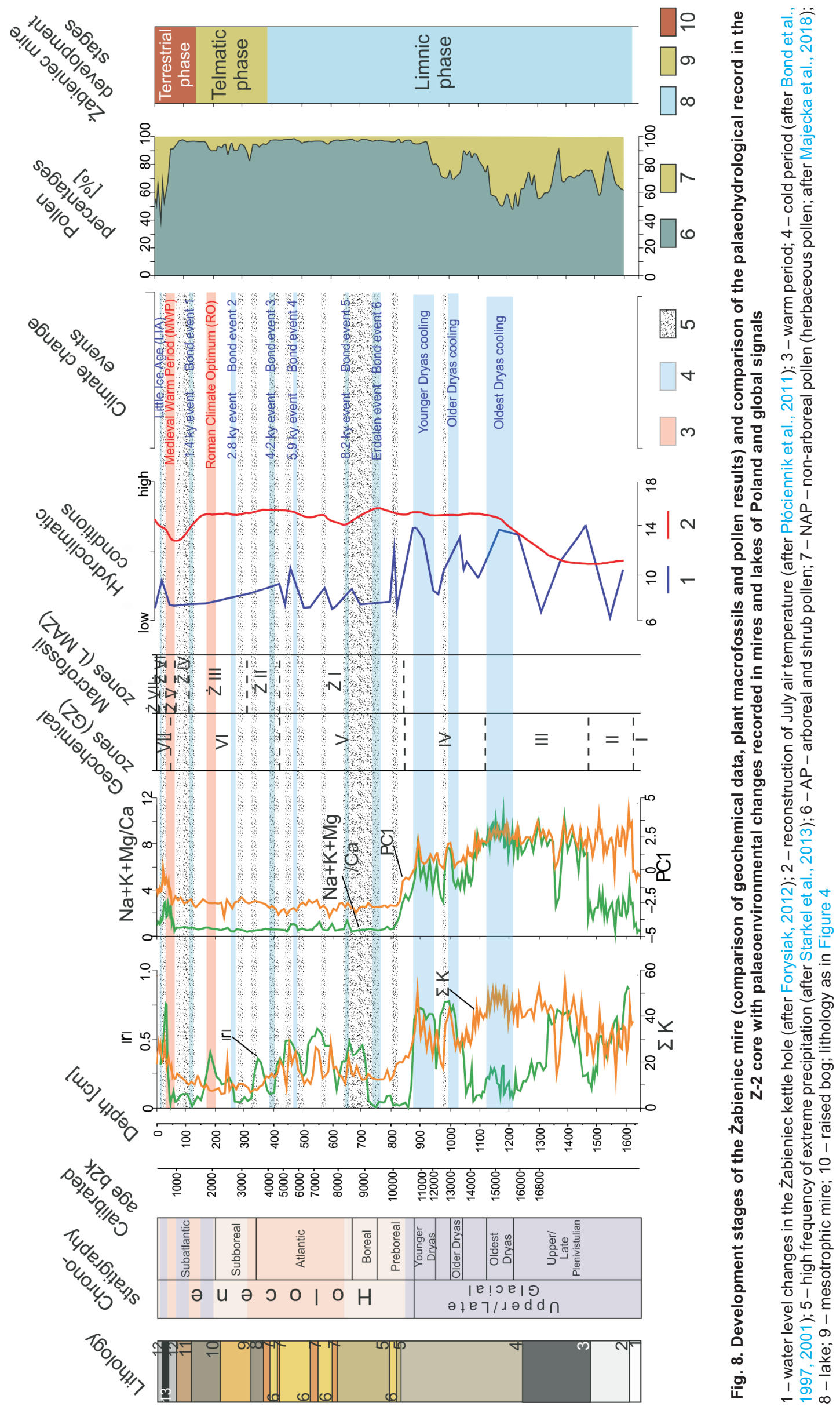


lake deposits from the Z-2 core, most elements correlated positively, especially in the warming phases of the Bølling and Allerød (Fig. 7).

The cooling of the Younger Dryas in Central Poland brought a return of steppe tundra (Ralska-Jasiewiczowa et al., 2004; Majecka et al., 2018). In sediments containing detrital-clay gyttja with an admixture of sand (up to $40 \%$ ), mineral matter and lithophilic elements increased. The sharp increase in such geochemical indices as $|\mathrm{r}|, \mathrm{KK}, \mathrm{Na}+\mathrm{K}+\mathrm{Mg} / \mathrm{Ca}$ and $\mathrm{PC} 1$ indicate rapid environmental changes towards cold and wet climate conditions during the Younger Dryas in the northern Łódź Hills.

PHASE 3: EARLY TO MIDDLE HOLOCENE LAKE SEDIMENTATION ENVIRONMENT $(9.00-3.80 \mathrm{~m} ; 11,500-4,130$ cal yr BP)

In the lake deposits studied, a record of Early to middle Holocene environmental changes is found in the fine detrital gyttja and coarse detrital gyttja interlayered with brown moss peat (depth 3.80-8.75 m). At the time, the lake basin was filling at a rate of $0.78 \mathrm{~mm} /$ year, lower than the average for the entire Z-2 profile. At the bottom of the succession, the organic matter content is in the range of $7-25 \%$, but then quickly increases to $93 \%$ at a depth of 8.02-8.12 m. A clear decline in the supply of material from mechanical denudation is recorded in concentrations of lithophile elements ( $\mathrm{Na}, \mathrm{K}$ and $\mathrm{Mg}$ ) dropping by well over half. The Fe/Mn and $\mathrm{Na}+\mathrm{K}+\mathrm{Mg} / \mathrm{Ca}$ rations, and the $|\mathrm{r}|$ and $\Sigma \mathrm{K}$ indices decrease significantly. In the lake deposits dated to the Preboreal, Boreal and the beginning of the Atlantic period, mainly fine detrital gyttja was documented, with a very high and stable organic matter content (84-96\%) and a variable $\mathrm{pH}$ of 4.7-6.5. The rate of gyttja sedimentation in the reservoir increased to $1.03 \mathrm{~mm} /$ year with a concurrent decrease in the content of lithophilic elements $(\mathrm{Na}, \mathrm{K}$ and $\mathrm{Mg}$ ). There is an increase in $\mathrm{Ca}, \mathrm{Mn}$ and $\mathrm{Cu}$, these being elements that migrate more easily as a result of chemical denudation (Borówka, 1992). The increase in $\mathrm{Na} / \mathrm{K}$ and $\mathrm{Ca} / \mathrm{Mg}$ ratios attests to vegetation growth in the lake's surroundings and to the previously dominant mechanical denudation being replaced by soil leaching processes and the sub-surface transport of soil solutions. In the section classified as Eoholocene and Mesoholocene, the total AP was high (98\%), mainly due to Betula, Pinus, Corylus and Alnus (Majecka et al., 2018).

$$
\text { PHASE 4: LATE HOLOCENE FEN AND TRANSITIONAL PEATLAND }
$$$$
(3.80-1.20 \mathrm{~m} ; 4,130-1,370 \text { cal yr BP) }
$$

Sedimentation in this phase are marked by a persistent propagation first of fen (eutrophic mire) and then transition bog (mesotrophic mire), as manifested by a gradual decrease in the proportion of brown mosses alongside an increase in that of sedge communities. The clear drop in iron concentration may have been caused by a change in the water cycle in the mid-moraine-upland forest ecosystem. A decrease in iron mobility and its immobilisation within the soil cover results from the cessation in surface gleying of soils and a predominance of oxidising conditions (Konecka-Betley, 2001). The $\mathrm{Na} / \mathrm{K}$ and $\mathrm{Ca} / \mathrm{Mg}$ ratios generally indicate an increase in chemical and mechanical denudation processes. From the beginning of this phase, the average sedentation rate of autochthonous organic matter was $1.2 \mathrm{~mm} /$ year.

In the middle part of the phase (depth 2.15-3.20 m) significant changes in $\mathrm{Na}$, and a slight increase in $\mathrm{K}$, contents, are recorded, while $\mathrm{Ca}$ content decreased. According to the age-depth model, the highest $\mathrm{Cu}$ concentration in the whole profile $(>67 \mu \mathrm{g} / \mathrm{g})$ and a marked increase in $\mathrm{Zn}$ concentrations (from 15.2 to $58.8 \mu \mathrm{g} / \mathrm{g}$ ) probably correlate with the activity of Bronze Age human communities. At the same time, there are significant differences in the $\mathrm{Na} / \mathrm{K}$ and $\mathrm{Cu} / \mathrm{Zn}$ ratios. The increase in the sum of concentration coefficients $(\Sigma K)$ and the sedimentary conditions dynamics index $|r|$ may constitute a geochemical record of matter originating from local deforestation in the Mroga and Mrożycy valleys being fed to the allochthonous peatbog by aeolian supply (Twardy, 2011).

At the top of this phase (depth 1.20-2.15 m) there was a slight increase in the concentrations of $\mathrm{Ca}, \mathrm{Mg}, \mathrm{Fe}$ and $\mathrm{Cu}$, with concurrent marked increases in the Fe/Mn, Cu/Zn and Na/K ratios. The index $|r|$ drops dramatically at the same time as a steady increase in the sum of concentration coefficients $\Sigma \mathrm{K}$. This situation attests to an increase in the water level in the peatland, the reappearance of reducing conditions and the predominance of chemical denudation processes. This subphase probably corresponds to the Iron Age and the subsequent Migration Period (1820-1370 years BP). During the period of Roman influence in the Iron Age, the fourth phase of the Holocene transformation of relief (Twardy, 2011) is considered the most important prehistoric phase as regards the Łódź region.

PHASE 5: LATE HOLOCENE RAISED BOG

$(1.20-0.48 \mathrm{~m} ; 1,370-680 \mathrm{cal}$ yr BP $)$

In the Z-2 core deposits at a depth of 0.48-1.2 m, raised bog peat, Sphagnum peat and valley peat occur, with a little mineral matter $(<3 \%)$ and decreasing $\mathrm{pH}$ (from 4.8 to 4.3 ). The raised-bog peat succession is marked by a several-fold increase in $\mathrm{Pb}$ and $\mathrm{Zn}$ content. These metals were found to correlate negatively with magnesium and calcium, which means that their concentration was not related to groundwater supply to the bog, but to atmospheric input. In this phase a significant increase in $\mathrm{Ca}, \mathrm{Fe}, \mathrm{Cu}$ and $\mathrm{Mg}$ concentrations was recorded. The sum of concentration coefficients $\Sigma \mathrm{K}$ also gradually increases, alongside a decrease in the sedimentation conditions dynamics index $|r|$. The beginning of raised bog peat accumulation occurred at $\sim 1474 \pm 35$ years BP (calibrated age: AD 530-660), i.e. the early Middle Ages. The sediment geochemical results given above indicate, however, that the immediate surroundings of the mire probably had no settlements at that time. The sum of NAP, which was initially only $\sim 3 \%$, increases to $10 \%$ only towards the end of this phase (Balwierz, 2010; Majecka et al., 2018).

PHASE 6: LATE HOLOCENE FEN AND TRANSITIONAL MIRE $(0.48-0.00 \mathrm{~m} ; 680$ cal yr BP until present)

This phase is associated with the initial sedentation of moss-sedge transition peat, then fen-moss peat, and at the top of the profile a return to moss-sedge transition peat. High variability in depositional conditions is indicated by rapid changes in the peat's mineral content (variations ranging from 4.8-64\%), a decrease in the peat sedimentation rate (from 1.53$-0.35 \mathrm{~mm} /$ year), fluctuations in the average correlation between the indicated metals $|r|$ (ranging from 0.05 to 0.76 ) and a clear increase in the sum of concentration coefficients $\Sigma \mathrm{K}$ (from 11 to 32 ).

The beginning of disturbance to the natural development of peat bogs towards oligotrophic Sphagnum peatlands can be correlated with human activity at the beginning of the late Middle Ages. The increase in the basin erosion index ( $\mathrm{Na}+$ $\mathrm{K}+\mathrm{Mg} / \mathrm{Ca}$ ) is a geochemical record of deforestation in the peat catchment area, probably associated with the nearby establishment of the village of Bielanki. The very low $\mathrm{Na} / \mathrm{K}$ index results from the beginning of mechanical denudation within the basin. Some of the elements were primarily transported with the mineral parts of soil ( $\mathrm{K}, \mathrm{Mg}, \mathrm{Fe}$ and $\mathrm{Pb}$ ), while others $(\mathrm{Mn}, \mathrm{Cu}$ and $\mathrm{Zn}$ ) came with its organic components. Agricultural intensifica- 
tion is indicated by the increased sum of NAP and by pollen from arable crops (Balwierz, 2010), as well as at numerous sites in the nearby Mroga valley, where the timing of soil cover erosion was determined (Twardy, 2008).

\section{THE CHARACTER AND INTENSITY OF ELEMENT MIGRATION} DURING THE LATE GLACIAL AND HOLOCENE

Geochemical studies on the northern Łódź Hills have demonstrated the main phases of Upper/Late Glacial and Holocene (natural and anthropogenic) environmental changes, on both regional and local scales. There is a direct correlation between chemical composition and lithology. Vertical plots of chemical components in the lake Żabieniec deposits, especially OM and lithophilic elements, reveal similar trends to the majority of biogenic accumulation sites in Central Poland (Forysiak, 2012).

The lacustrine carbonate sediments at the Żabieniec site are an indicator of the specific hydrological regime of the Late Glacial, which was conditioned by the intermittent disappearance of permafrost and the propagation of vegetation. In the carbonate deposits studied, the average $\mathrm{Ca} / \mathrm{Mg}$ ratio was 47.9 , while $\mathrm{Na} / \mathrm{Ca}$ was 0.01 , and $\mathrm{K} / \mathrm{Ca}$ was 0.07 . These differences in composition, especially differences in $\mathrm{K} / \mathrm{Ca}$, most probably result from the sequence of the salt crystallisation of particular cations water-transported into the lake. The last to precipitate are potassium and magnesium salts, cations of which can be removed from the tank by water outflow after precipitation of $\mathrm{Fe}$, $\mathrm{Ca}$ and $\mathrm{Na}$. Small amounts of $\mathrm{K}$ in carbonate sediments have also been documented at many other locations with biogenic deposits in Central Poland by Goździk and Konecka-Betley (1992) and Pawłowski et al., (2016b). However, the increased proportion of calcium carbonate in lake sediments may be associated with an increase in water level in the lake or with an increase in deeper groundwater charging the lake. From the diagram showing the main trends of water level changes in the Żabieniec basin (Fig. 8), it appears that sediments with an admixture of calcium carbonate accumulated under variable humidity conditions. Analysis of Cladocera species composition suggest an increased water level in the basin during the initial and final carbonate deposition phase (Pawłowski, 2012). Due to the lack of dating control, it is difficult to unambiguously state whether the beginning of deposition of carbonate-rich sediments correlates with the interval of severe climatic conditions during the recession of the Vistulian ice-sheet after the Leszno (23-24 ka BP) and Poznań (19-20 ka BP) phases, or with the Pomeranian Phase (16-17 ka BP) (Kasprzak, 2003; Marks 2012). The second phase of increased humidity, and of the lake receiving increased delivery of $\mathrm{Ca}^{2+}$ and $\mathrm{HCO}_{3}^{-}$ions from the dissolution of the rocks in the catchment, can be correlated with the Older Dryas, with the transition to the Bølling warming in the upper part.

The plotted curves of $\mathrm{K}, \mathrm{Na}, \mathrm{Mg}$ and Fe concentrations show a very similar pattern, which is reflected in the strong positive correlations between the contents of these components in almost all parts of this profile (Fig. 8). The highest concentration of lithophilic elements was recorded for lake sediments deposited in the Upper/Late Plenivistulian and Late Glacial. Although the contents of $\mathrm{K}, \mathrm{Na}$ and $\mathrm{Mg}$ show significant vertical variation, the proportion of these metals often exceeds local geochemical background levels by a factor of ten. These metals represent the greatest migration of elements at geochemical levels GZ IIGZ IV and the ratio of their sum to calcium is $\sim 8$ (Fig. 5). Similar catchment erosion rates have been recorded for Late Glacial lake and peat deposits at many sites around Łódź (Forysiak, 2012).
A clear increase in the $\mathrm{Na} / \mathrm{K}$ ratio in the Holocene organic sedimentary succession was only found from the beginning of the Atlantic. During this interval, the concentration index for calcium increases, and the $|r|$ index exceeds 0.5 on three occasions. The reason for the large increase in surface and subsurface leaching of the moraine plateau catchment was probably high precipitation. For these intervals, the sum of concentration coefficients of these elements is highest in the entire Holocene succession and often exceeds 20 . In the Atlantic period humidity conditions were variable, while phases of increased supply of $\mathrm{Na}$ and $\mathrm{Ca}$ and increased correlation between other metals correlate with extremes in precipitation as distinguished by Starkel et al. (2013; Fig. 8). The stratigraphic variablility of these Holocene lake successions may also have been influenced by the average sediment accumulation rate. Despite the small number of observations $(N=10)$, significant positive correlation coefficients were found between the sediment accumulation rate and the average concentration of such elements as $\mathrm{Na}$, $\mathrm{Cu}$ and $\mathrm{Zn}$. At times when the sediment accumulation rate was above the average for the entire profile (i.e. $0.9 \mathrm{~mm} /$ year) the $\mathrm{Na} / \mathrm{K}$ ratio often exceeded 1.3, which is 10 times higher than the $\mathrm{Na} / \mathrm{K}$ ratio in the mineral deposits that form the lake catchment. This situation indicates selective $\mathrm{Na}$ concentration resulting from leaching and has been recorded in other upland lakes (Borówka, 1992; Okupny et al., 2013; Karasiewicz, 2019). The observed changes in the lithology and geochemical record of the Żabieniec kettle-hole seem to have been largely triggered by local hydrogeology conditions and regional hydroclimatic shifts. The rapid changes in the geochemical ratios, mainly $|r|$ index or erosion ratio, may reflect global-scale variability expressed, for instance, as Bond cycles (Bond et al., 1997, 2001).

The change in denudation patterns in the peat bog basin which began over the past millennium, and the associated increase in supply of $\mathrm{K}, \mathrm{Mg}, \mathrm{Na}$ and $\mathrm{Fe}$ relative to $\mathrm{Ca}$ is most characteristic of the Subatlantic. This phase was preceded by a disturbance in the recirculation of elements, especially $\mathrm{Ca}, \mathrm{Mg}$ and $\mathrm{Cu}$. Periodic deforestation initially caused an increase in $\mathrm{Ca}, \mathrm{Mg}$ and $\mathrm{Cu}$ concentrations, followed by a drop in their supply to the peat bog. Increased outflow of minerals from the soils surrounding the lake may have been associated with a sharp decline in plant transpiration favouring an increase in surface and ground runoff, with inhibition of bioaccumulation and with acidification of soils. Such a mechanism of geochemical consequences of basin deforestation, including a depletion of mineral resources that easily migrate in aqueous solutions, was suggested by Borówka (1992) for moraine plateaux of northwestern Poland.

The Early Holocene is distinguished by decreased supply of almost all elements, including the lowest $\Sigma \mathrm{K}$ values at the boundary between the Atlantic and Subboreal. These changes were preceded by a decrease in the sediment accumulation rate to just over $0.5 \mathrm{~mm} /$ year. In the Holocene biogenic succession, due to the gradual overgrowing of the lake basin and the beginning of the sedentation of autochthonous organic matter in the reservoir, a marked change is seen in the structure of the concentration coefficients for particular metals. Increased leaching of $\mathrm{Cu}$ and $\mathrm{Zn}$ may have been favoured by vegetation cover dominated by pine (Majecka et al., 2018), producing fulvic and humic-fulvic litter with properties aggressive towards mineral substances. In the Holocene, the soil permeability increased due to development of the soil structure and its consequent increased porosity. The concentrations of trace elements are comparable to those in other mires in Central Poland (Słowiński et al., 2016; Dobrowolski et al., 2017). However, the 
concentrations of $\mathrm{Pb}$ and $\mathrm{Zn}$ are much higher than mean values for peatlands elsewhere in Poland. The maximum content of $\mathrm{Pb}$ in peat deposits from Żabieniec is $82.8 \mu \mathrm{g} / \mathrm{g}$ and the mean content for Poland is $7 \mu \mathrm{g} / \mathrm{g}$. The maximum content of $\mathrm{Zn}$ in peat deposits from Żabieniec is $87 \mu \mathrm{g} / \mathrm{g}$, while the mean content of $\mathrm{Zn}$ for peatlands in Poland is $25 \mathrm{\mu g} / \mathrm{g}$ (Bojakowska and Lech, 2008).

CAUSES OF SEDIMENTARY GEOCHEMICAL VARIATION AT THE ŻABIENIEC MIRE

The first component (PC1) is partly connected with the allochthonous component, comprising mineral matter and the lithophilic elements $\mathrm{Na}, \mathrm{K}$ and $\mathrm{Mg}$ (Fig. 6B). In aqueous environments, these lithogeochemical components have been shown to be good measures of the intensity of mechanical denudation and the supply of clastic material from the associated lake catchment (Foster and Dearing, 1987; Pawłowski et al., 2016a). The co-existence of these elements can be regarded as a universal phenomenon that results from the absorption of metals by aluminosilicate clay minerals (Rydelek, 2013). Because of the low correlation of organic matter, $\mathrm{Na}$ and $\mathrm{K}$ with $\mathrm{Fe}$ content in the lake deposits (Fig. 7), the sorptive role of iron oxides and clay minerals was dominant.

The second component (PC2) mainly explains the variation of $\mathrm{Cu}, \mathrm{Zn}$ and organic matter. The maximum values of these lithogeochemical elements can be found in fine detrital gyttja and all types of peat deposits. Organic matter content correlates positively with $\mathrm{Fe} / \mathrm{Mn}$ and $\mathrm{Cu} / \mathrm{Zn}$ ratios in the Late-Glacial lake deposits, which suggests that the relative changes in biological productivity in the lake were dependent on water fertility, the depth and dynamics of the reservoir and the oxygenation of the bottom waters. The anaerobic conditions prevailing in the bottom part of the water column limited the mineralisation of organic compounds falling from the epilimnion. The several periods of high $\mathrm{Cu}$ content in the lake deposits are the main indicator (and smaller share in $\Sigma \mathrm{K}$ ) that this trace element was also supplied by chemical denudation occurring in the reservoir catchment. The $\mathrm{Zn}$ concentration in the sediments is controlled by sorption-desorption reactions in which the $\mathrm{pH}$ is the most important factor, but organic carbon content and clay content are also significant (Borówka, 1992). The occurrence of $\mathrm{Zn}$ in peat deposits in the top part of the profile may also be related to allogenic atmospheric supply and anthropogenic influence. A low correlation between $\mathrm{Zn}$ and other trace elements ( $\mathrm{Cu}$ and $\mathrm{Pb}$ ) was observed in the Neoholocene peat deposits. Differences in the maximum values through $\mathrm{Zn}$ being one of the most mobile and soluble elements, easily assimilated by plants such as Betula.

\section{PALAEOGEOGRAPHICAL CONCLUSIONS}

Based on the macrofossils and geochemical proxies, the development history of the Żabieniec mire has a classic succession from limnnic to telmatic and then terrestrial environments. Data from the core analysed allows reconstruction of the palaeoenvironment of the lake-mire ecosystem studied with respect to regional changes in climate, water conditions and denudation processes in the northern part of the Łódź Hills during the last $16.8 \mathrm{ka}$. The vertical variability in chemical composition of the biogenic deposits records changes taking place not only in the lake, but also in its surroundings. The chemical composition of these deposits depends on the quantity and quality of the mineral material and on the chemical composition of the water entering the lake basin. Analysis of macrofossil remains and geochemical composition in the Żabieniec mire allows us to re- construct the history of geochemical migration of elements in the northern part of the Łódź Hills in the Late Glacial and Holocene, as well as demonstrating the influence of climate conditions and human activity on the environment.

Upper/Late Glacial (16.8-11.5 ka cal BP). Limnic sedimentation in the northern Łódź Hills started in the decline of the Upper Plenivistulian, and is constrained by radiocarbon dating ( 16.8 ka BP) and pollen analysis of the Z-2 core (Majecka et al., 2018). The presence of organic-mineral sediments in the Żabieniec mire basin is a regional exception. Elsewhere in the region, all known endorheic depressions with biogenic Eemian and Early Vistulian deposits within denuded uplands or slopes were eventually filled with mineral sediments, or dissected and included into systems of denudation valleys and river valleys in the Plenivistulian. The lithology of Late Glacial deposits filling the Żabieniec basin is dominated by lacustrine silt with sand and detrital-clay gyttja with an admixture of $\mathrm{CaCO}_{3}$. The rapidly changing contents of organic matter and elements in individual layers of the lake basin record changes taking place not only in the basin, but also in its surroundings. The highest contents of $\mathrm{CaCO}_{3}$ and $\mathrm{Ca}$ attest to increasing decalcification of the glacial and fluvioglacial deposits surrounding the reservoir at the decline of the Plenivistulian and the beginning of the Late Glacial. Contents of lithophilic elements ( $\mathrm{Na}, \mathrm{Mg}$ and $\mathrm{K}$ ) in the lake deposits are on average much higher than recorded in Late Glacial successions in biogenic accumulation sites of the Polish Lowland elsewhere. This is a record of intense denudation on adjacent slopes and uplands in periglacial climate conditions.

Holocene (11.5 ka cal BP to present). A substantial part of the biogenic succession is composed of lake and peat deposits detrital-clay gyttja, detrital gyttja with a variable content of plant remains and thin intercalations of brown moss peat, fen peat, transition peat and peat bog. The diverse geochemical signature in this part of the profile reflects the role of the local geochemical background and denudation processes in gyttja and peat deposition. This interval also revealed a more dynamic content of the lithogeochemical elements, usually at the lithological contact of different layers of the peat. These periods are interrupted by phases in which low levels of elements were supplied into the accumulating deposits (known as "geochemical silence"). However, in the Holocene, selective migration of copper and calcium in aqueous solution increased. Clear fluctuations in the copper and sodium contents in the deposits may indicate periodic changes in the character of biogenic accumulation due to water level fluctuations. In turn, the relatively low values of $\mathrm{Fe} / \mathrm{Mn}$ ratio seem to indicate changing redox conditions at this site, which might have been associated with the autogenous hydroseral succession from lake to mire. Human activity recorded in the Z-2 core is reflected in an increase in mineral matter in organic deposits, a decrease in $\mathrm{pH}$, and an increase in elements activated by mechanical denudation. These results are consistent with other palaeoecological analyses, e.g a decrease in the presence of AP and the appearance of species indicative of human activity (Forysiak et al., 2011).

Acknowledgements. The authors thank the Polish Ministry of Science and Higher Education for funding the study "Changes in the Environment of the Łódź Hills (Wzniesienia Łódzkie) during the Vistulian (Weichselian) and Holocene in the light of interdisciplinary palaeoecological research of the Żabieniec mire" (no 2P04E02228). We are grateful to B. Kosińska, J. Tomkowiak and J. Sławińska who performed the laboratory and chronostratigraphy analysis. We would like to thank $O$. Juschus and two anonymous reviewers for careful reading of our manuscript. Their constructive comments and suggestions helped to improve the quality of this article. 


\section{REFERENCES}

Balwierz, Z., 2010. Analiza pyłkowa osadów torfowiska Żabieniec (in Polish). In: Torfowisko Żabieniec: warunki naturalne, rozwój i zapis zmian paleoekologicznych w jego osadach (eds. J. Twardy, S. Żurek and J. Forysiak): 179-188. Bogucki Wyd. Nauk., Poznań

Bezkowska, G., 1997. The geocomplex of closed depressions near Zduńska Wola (in Polish with English summary). Acta Universitatis Lodziensis, Folia Geographica Physica, 1: 89-107.

Blott, S.J., Pye, K., 2001. Gradistat: a grain size distribution and statistics package for the analysis of unconsolidated sediments. Earth Surface Processes and Landforms, 26: 1237-1248.

Bojakowska, I., Lech, D., 2008. Variance of trace elements contents in peats occurred in Poland area (in Polish with English summary). Zeszyty Naukowe Politechniki Śląskiej: Górnictwo, 285: $31-41$

Bond, G., Kromer, B., Beer, J., Muscheler, R., Evans, M.N., Showers, W., Hoffmann, S., Lotti-Bond, R., Hajdas, I., Bonani, G., 2001. Persistent solar influence on North Atlantic climate during the Holocene. Science, 294: 2130-2136.

Bond, G., Showers, W., Cheseby, M., Lotti, R., Almasi, P., deMenocal, P., Priore, P., Cullen, H., Hajdas, I., Bonani, G., 1997. A pervasive millennial-scale cycle in North Atlantic. Science, 278: 1257-1266.

Borówka, R.K., 1992. The pattern and magnitude of denudation in intraplateau sedimentary basins during the Vistulian and Holocene (in Polish with English summary). Adam Mickiewicz University Press, Seria Geografia, 54: 1-177.

Bronk Ramsey, C., 2009. Bayesian analysis of radiocarbon dates. Radiocarbon, 51: 337-360.

Bukowska-Jania, E., 2003. The role of glacier systems in the migration of calcium carbonate in the natural environment (with particular reference to Svalbard and the late glacial areas in NW Poland) (in Polish with English summary). University of Silesia Press, Prace Naukowe Uniwersytetu Śląskiego, 2103: 1-247.

Charman, D.J., 2002. Peatlands and Environmental Change. Wiley, Chichester

Davinson, W., 1993. Iron and manganese in lakes. Earth-Science Reviews, 34: 119-163.

Dobrowolski, R., Ziułkiewicz, M., Okupny, D., Forysiak, J., Bałaga, K., Alexandrowicz, W.P., Buczek, A., Hałas, S., 2017. Origin and Neoholocene evolution of spring-fed fens in Wardzyń, Łódź Upland, Central Poland. Geological Quarterly, 61 (2): 413-434.

Engstrom, D.R., Wright, H.E., 1984. Chemical stratigraphy of lake sediments as a record of environmental change. In: Lake Sediments and Environmental History (eds. E.Y. Haworth and J.W.G. Lund): 11-69. Leicester University Press, Leicester.

Folk, R.L., Ward, W.C., 1957. Brazos River bar: a study in the significance of grain size parameters. Journal of Sedimentary Petrology, 27: 3-26.

Fortescue, J.A.C., 1980. Environmental Geochemistry. A Holistic Approach. Springer, New York.

Forysiak, J., 2012. Record of changes in the natural environment of the Late Weichselian and Holocene preserved in the sediments of peatlands of the Łódź region (in Polish with English summary). Acta Geographica Lodziensia, 99: 1-163.

Forysiak, J., Obremska, M., Twardy, J., 2011. Records on anthropogenic environmental changes in small river valleys in the vicinity of Łowicz (central Poland): their significance for the reconstruction of Late Holocene settlement tendencies. Bulletin of Geography - Physical Geography Series, 4: 7-20.

Forysiak, J., Majecka, A., Marks, L., Tołoczko-Pasek, A., Okupny, D., 2017. Lithological features of the infillings of selected closed depressions int Łódź Upland (in Polish with English summary). Acta Geographica Lodziensia, 106: 195-210.

Forysiak, J., Twardy, J., 2010. Budowa geologiczna i paleogeografia torfowiska Żabieniec i jego otoczenia (in Polish). In: Torfowisko Żabieniec: warunki naturalne, rozwój I zapis zmian paleoekologicznych w jego osadach (eds. J. Twardy, S. Żurek and J. Forysiak): 17-42. Bogucki Wyd. Nauk., Poznań.

Foster, I.D.L., Dearing, J.A., 1987. Lake catchments and environmental chemistry: a comparative study of contemporary and historical catchment processes in Midland England. GeoJournal, 14: 285-297.

Goździk, J., Konecka-Betley, K., 1992. Late Vistulian carbonaceous formations in outflow closed depressions of the Bełchatów brown coal strip mine. Part II. Chemical and mineral composition (in Polish with English summary). Roczniki Gleboznawcze, 43: 113-124.

Hammer, O., Harper, D.A.T., Ryan, P.D., 2001. PAST: Paleontological statistics software package for education and data analysis. Palaeontologica Electronica, 4: 1-9.

Heiri, O., Lotter, A.F., Lemcke, G., 2001. Loss on ignition as a method for estimating organic and carbonate content in sediments, reproducibility and comparability of results. Journal of Paleolimnology, 25: 101-110.

Kalettka, T., Rudat, C., 2006. Hydrogeomorphic types of glacially created kettle holes in North-East Germany. Limnologica, 36: 54-64.

Karasiewicz, T.M., 2019. The kettle-hole mire as archives of postglacial changes in biogenic sedimentation (Tuchola Forest, north-Central Poland). Catena, 176: 26-44.

Karasiewicz, M.T., Hulisz, P., Noryśkiewicz, A.M., Krześlak, I., Świtoniak, M., 2014. The record of hydroclimatic changes in the sediments of a kettle-hole in a Young Glacial landscape (north-central Poland). Quaternary International, 328-329: 264-276.

Karasiewicz, T.M., Hulisz, P., Noryśkiewicz, A.M., StachowiczRybka, R., Michalski, A., Dąbrowski, M., Gamrat, W.W., 2017. The impact of postglacial palaeoenvironmental changes on the properties of sediments in the kettle hole at Jurki (NE Poland). Geological Quarterly, 61 (2): 319-333.

Kasprzak, L., 2003. Model of the Vistulian ice-sheet sedimentation in the Wielkopolska Lowland (in Polish with English summary). Adam Mickiewicz University Press, Seria Geografia: 66: 1-216.

Katz, N.J., Katz, S.V., Skobiejeva, E.I., 1977. Atlas of Macrofossils from Peats. Nedra, Moskva.

Klatkowa, H., 1997. Closed depressions in central Poland and a significance of their fillings to the palaeogeographical interpretation (in Polish with English summary). Acta Universitatis Lodziensis, Folia Geographica Physica, 1: 23-45.

Konecka-Betley, K., 2001. Reconstruction of Late Pleistocene and Holocene pedological processes in the Central Poland (in Polish with English summary). Roczniki Gleboznawcze, 52: 99-118.

Konecka-Betley, K., Czępińska-Kamińśka, D., 1979. Typology of soils development from shallow silty formations of the Skierniewicka Upland (in Polish with English summary). Roczniki Gleboznawcze, 30: 95-110.

Koretsky, C.M., Haas, J.R., Ndenga, N.T., Miller, D., 2006. Seasonal variantions in vertical redox stratification and potential influence on trace metal speciation in minerotrophic peat sediments. Water, Air and Soil Pollution, 173: 373-403.

Lamentowicz, M., Balwierz, Z., Forysiak, J., Płóciennik, M., Kittel, P., Kloss, M., Twardy, J., Żurek, S., Pawlyta, J., 2009. Multiproxy study of anthropogenic and climatic changes in the last two millennia from a small mire in central Poland. Hydrobiologia, 631: 213-230.

Legendre, P., Birks, H.J.B., 2012. From classical to canonical ordination. In: Tracking Environmental Change Using Lake Sediments, 5. Data Handing and Numerical Techniques (eds. H.J.B. Birks, A.F. Lotter, S. Juggings and J.P. Smol): 201-248. Springer, Dordrecht.

Łącka, B., Starnawska, E., Kuźniarski, M., Chróst, L., 1998. Mineralogy and geochemistry of the Lake Gościąż Holocene sediments. In: Lake Gościąż, Central Poland. A Monography Study, Part 1 (eds. M. Ralska-Jasiewiczowa, T. Goslar, T. Madeyska 
and L. Starkel): 196-202. W. Szafer Institute of Botany Polish Academy of Sciences, Kraków.

Majecka, A., Balwierz, Z., Forysiak, J., Twardy, J., 2018. Eemian and Vistulian (Weichselian) development of the meltout depression on the watershed between the Mroga and Mrożyca Rivers (Central Poland) based on lithological and pollen analysis. Quaternary International, 467, part A: 79-95.

Mangiamelli, P., Chen, S.K., West, D., 1996. A comparison of SOM neural network and hierarchical clustering methods. European Journal of Operational Research, 93: 402-417.

Marks, L., 2012. Timing of the Late Vistulian (Weichselian) glacial phases in Poland. Quaternary Science Reviews, 44: 81-88.

Mauquoy, D., van Geel, B., 2007. Mire and peat macros. In: Encyclopedia of Quaternary Science (ed. S.A. Elias): 2315-2336. Elsevier, Amsterdam.

Mirek, Z., Piękoś-Mirkowa, H., Zając, A., Zając, M., 2002. Flowering plants and pteridophytes of Poland. A checklist. Biodiversity of Poland, 1: 1-442.

Ochyra, R., Żarnowiec, J., Bednarek-Ochyra, H., 2003. Census catalogue of Polish mosses. Biodiversity of Poland, 3: 1-372.

Okupny, D., Fortuniak, A., Tomkowiak, J., 2013. Denudation features of the Late Vistulian (Weichselian Late Glacial) preserved in the geochemical analysis of the biogenic deposits of the Łódź Region (in Polish with English summary). Acta Geographica Lodziensia, 101: 89-99.

Okupny, D., Żurek, S., Forysiak, J., 2014. Spatial pattern of mire distribution of the Lodz Region (in Polish with English summary). Studia Limnologica et Telmatologica, 8: 81-91.

Okupny, D., Malkiewicz, M., Pawłowski, D., LudwikowskaKędzia, M., Borówka, R.K., Forysiak, J., Michczyński, A., Jucha, W., Cybul, P., Żurek, S., 2019. Late Glacial palaeoenvironmental changes in the southern part of the Holy Cross Mountains based on the "Białe Ługi" peatland record. Studia Quaternaria, 36: 119-135.

Okupny, D., Borówka, R.K., Cedro, B., Sławińska, J., Tomkowiak, J., Michczyński, A., Kozłowska, D., Kowalski, K., Siedlik, K., 2020. Geochemistry of a sedimentary section at the Wąwelnica archaeological site, Szczecin Hills (Western Pomerania). Acta Geographica Lodziensia, 110: 169-186.

Pawłowski, D., 2012. Early development of Late Vistulian (Weichselian) lacustrine sediments in the Żabieniec swamp (central Poland). Geochronometria, 39: 197-211.

Pawłowski, D., Borówka, R.K., Kowalewski, G., Luoto, T.P., Milecka, K., Nevalainen, L., Okupny, D., Płóciennik, M., Woszczyk, M., Tomkowiak, J., Zieliński, T., 2016a. The response of flood-plain ecosystems to the Late Glacial and Early Holocene hydrological changes: A case study from a small Central European river valley. Catena, 147: 411-428.

Pawłowski, D., Borówka, R.K., Kowalewski, G.A., Luoto, T.P., Milecka, K., Nevalainen, L., Okupny, D., Tomkowiak, J., Zieliński, T., 2016b. Late Weichselian and Holocene record of the palaeonvironmental changes in a small river valley in Central Poland. Quaternary Science Reviews, 135: 24-40.

Płóciennik, M., Self, A., Birks, H.B.J., Brooks, S.J., 2011. Chironomidae (Insecta: Diptera) succession in Żabieniec bog and its palaeolake (central Poland) through the Late Weichselian and Holocene. Palaeogeography, Palaeoclimatology, Palaeoecology, 307: 150-267.

Ralska-Jasiewiczowa, M., Latałowa, M., Wasylikowa, K., Tobolski, K., Madeyska, E., Wright, H.E.Jr., Turner, C. (eds.), 2004. Late Glacial and Holocene history of vegetation in Poland based on isopollen maps. W. Szafer Institute of Botany, Polish Academy of Sciences, Kraków.

Reimer, P.J., Bard, E., Bayliss, A., Beck, W.J., Blackwell, P.G., Bronk Ramsey, Ch., Buck, C.E., Cheng, H., Edwards, R.L., Friedrich, M., Grootes, P.M., Guilderson, T.P., Haflidason, H., Hajdas, I., Hatte, Ch., Heaton, T.J., Hofmann, D.L., Hogg, A.G., Hughen, K.A., Kaiser, K.F., Kromer, B., Manning, S.W., Niu, M., Reimer, R.W., Richards, D.A., Scoett, E.M., Southon, J.R., Staff, R.A., Turney, Ch.S.M., van der Plicht, J., 2013. IntCal13 and Marine13 radiocarbon age calibration curves, 0-50,000 years cal BP. Radiocarbon, 55: 1869-1887.

Rydelek, P., 2013. Origin and composition of mineral constituents of fen peats from Eastern Poland. Journal of Plant Nutrition, 36: 911-928.

Shotyk, W., 1996. Peat bog archives of atmospheric metal deposition: geochemical evaluation of peat profiles, natural variations in metal concentration and metal enrichments factors. Environmental Reviews, 4: 149-183.

Słowiński., M., Marcisz., K., Płóciennik, M., Obremska, M., Pawłowski, D., Okupny, D., Słowińska, S., Borówka, R.K., Kittel, P., Forysiak, J., Michczyńska, D.J., Lamentowicz, M., 2016. Drought as a stress driver of ecological changes in peatland - a study of peatland development between 3500 BCE and $200 \mathrm{BCE}$ in central Poland. Palaeogeography, Palaeoclimatology, Palaeoecology, 461: 272-291.

Starkel, L., Michyczyńska., D.J., Krąpiec, M., Margielewski, W., Nalepka, D., Pazdur, A., 2013. Progress in the Holocene chrono-climatostratigraphy of Polish territory. Geochronometria, 40: $1-21$.

Tobolski, K., 2000. A Guide for Identification of Peat and Lake Sediments (in Polish with English summary). Wyd. Nauk., PWN, Warszawa.

Tolksdorf, J.F., Kaiser, K., 2012. Holocene eolian dynamics in the European sand-belt As indicator by geochronological data. Boreas, 41: 408-421.

Twardy, J., 2008. The transformation of relief of central part of Middle Poland under the human impact (in Polish with English summary). University of Lodz Press, Łódź.

Twardy, J., 2011. Influence of man and climate changes on relief and geological structure transformation in Central Poland since the Neolithic. Geographica Polonica, 84: 163-178.

Walanus, A., 2000. The statistical significance of the conclusions of the quantitative analyses of research on the example of Upper Quaternary (in Polish with English summary). Geologia, Kwartalnik AGH, 26: 1-59.

Żurek, S., 1990. Interrelation between the peat-forming process and the elements of natural environment eastern Poland (in Polish with English summary). Roczniki Nauk Rolniczych, Seria D, Monografie, 220: 1-174. 